This article was downloaded by: [University of Minnesota - Morris] On: 25 October 2013, At: 09:59

Publisher: Routledge Informa Ltd Registered in England and Wales Registered Number: 1072954 Registered office: Mortimer House, 37-41 Mortimer Street, London W1T 3J H, UK

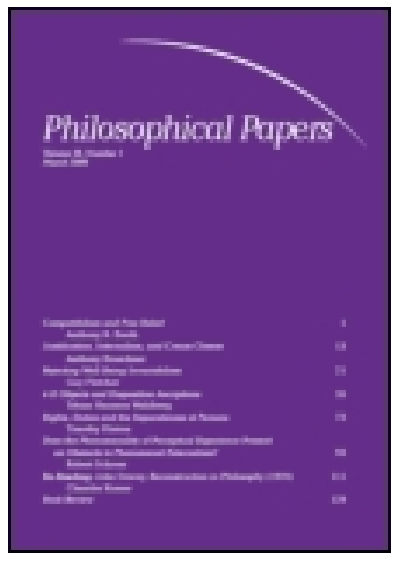

\title{
Philosophical Papers
}

Publication details, including instructions for authors and subscription information:

http:// www.tandfonline.com/loi/ rppa20

\section{Honor War Theory: Romance or Reality?}

Daniel Demetriou ${ }^{a}$

a University of Minnesota, Morris

Published online: 24 Oct 2013.

To cite this article: Daniel Demetriou (2013) Honor War Theory: Romance or Reality?, Philosophical Papers, 42:3, 285-313, DOI: 10.1080/05568641.2013.854021

To link to this article: http:// dx.doi.org/ 10.1080/ 05568641.2013.854021

\section{PLEASE SCROLL DOWN FOR ARTICLE}

Taylor \& Francis makes every effort to ensure the accuracy of all the information (the "Content") contained in the publications on our platform. However, Taylor \& Francis, our agents, and our licensors make no representations or warranties whatsoever as to the accuracy, completeness, or suitability for any purpose of the Content. Any opinions and views expressed in this publication are the opinions and views of the authors, and are not the views of or endorsed by Taylor \& Francis. The accuracy of the Content should not be relied upon and should be independently verified with primary sources of information. Taylor and Francis shall not be liable for any losses, actions, claims, proceedings, demands, costs, expenses, damages, and other liabilities whatsoever or howsoever caused arising directly or indirectly in connection with, in relation to or arising out of the use of the Content. 
This article may be used for research, teaching, and private study purposes. Any substantial or systematic reproduction, redistribution, reselling, loan, sub-licensing, systematic supply, or distribution in any form to anyone is expressly forbidden. Terms \& Conditions of access and use can be found at http://www.tandfonline.com/page/terms-andconditions 
Philosophical Papers

Vol. 42, No. 3 (November 2013): 285-313

\title{
Honor War Theory: Romance or Reality? Daniel Demetriou
}

\begin{abstract}
Just War Theory (JWT) replaced an older 'warrior code,' an approach to war that remains poorly understood and dismissively treated in the philosophical literature. This paper builds on recent work on honor to address these deficiencies. By providing a clear, systematic exposition of 'Honor War Theory' (HWT), we can make sense of paradigm instances of warrior psychology and behavior, and understand the warrior code as the martial expression of a broader honor-based ethos that conceives of obligation in terms of fair competition for prestige. Far from being a romantic and outmoded approach to war, HWT accounts for current conflicts and predicts moral intuitions that JWT either rejects or cannot comfortably accommodate. So although it is not recommended as a replacement for JWT, there is good reason think that a fully mature, realistic, and yet properly normative theory of war ethics will incorporate a variety of insights from HWT.
\end{abstract}

There are two laws: one of honor, and one of justice, in many matters quite opposed...

—Montaigne, 'On Custom'

\section{Taking Warriors Seriously}

'Just War Theory' (JWT) has two senses. Its non-substantive interpretation takes it to name the view saying war is sometimes morally permissible (contrary to pacifism) and yet that morality norms war just as it does any other sort of activity (contrary to realism). Its substantive interpretation takes it to name a particular view of what the moral constraints on war are, viz., those constraints loosely associated with justice and advocated for by figures such as Augustine, Aquinas, Grotius, and Walzer. Ethicists are not always as explicit as they should be about which sense they are invoking when they discuss JWT. More historicallyinformed theorists of war, conscious of the substantive commitments

Routledge

Taylor \& Francis Group
ISSN 0556-8641 print/ISSN 1996-8523 online (C) 2013 The Editorial Board, Philosophical Papers DOI: $10.1080 / 05568641.2013 .854021$

http://www.tandfonline.com

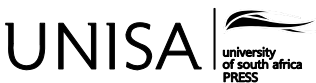


JWT often assumes, are aware that that JWT is not the only approach to war's moral limits. Sometimes they note that JWT supplanted, if not an articulated theory of moral war, at least an 'ethos' that had a great deal to say about when and how to fight (Bonadonna 2010; French 2003; Lebow 2010; Olsthoorn 2005; Robinson 2006 and 2007, among others). ${ }^{1}$

Nonetheless, all too often the gestures made in the direction of this older ethos misrepresent it or downplay its perennial intuitiveness as 'romantic.' For instance, Paul Kahn has on multiple occasions referred to the code of chivalry in his discussions of riskless warfare. He points out that riskless warfare seems somehow problematic, and yet

that riskless warfare even raises a moral puzzle may seem, at first, no more than a lingering cultural remnant of a world in which battle was governed by rules of chivalry - a romantic ideal that has been out of touch with actual combat for most of this century. (Kahn 1999: 2)

Kahn goes on to suggest that riskless warfare is problematic because of the principle of reciprocal self-defense: two coerced parties meant to impose harm against each other may use violence to defend themselves (Kahn 2003: 3ff.). Kahn's principle may succeed in condemning riskless warfare. Nonetheless, it would be worth knowing whether this older, abandoned ethos provides another good reason to condemn riskless warfare. That is a question of morality proper. Moreover, it would be interesting to know whether it is Kahn's principle, or instead a deep-seated and possibly innate commitment to this older ethos, that generates our repugnance of riskless warfare. That is a question of moral psychology. If the rules of 'chivalry' can be shown to provide good reasons against riskless warfare, and further can be seen to lie behind our intuitions against it even today, then they could hardly be said to lack real-world relevance.

\footnotetext{
1 Readers familiar with those works will note that whereas they sometimes portray honor in terms of integrity and self-sacrifice, the present account understands honor-or more precisely, the honor ethos-in terms of fair competition for status. In any case, the presentation I give here of honor is very much in keeping with what Kahn and Walzer have in mind in their discussions of chivalry and aristocratic warfare.
} 
By suggesting that this older approach to war ethics is 'out-of-touch' and 'romantic,' Kahn echoes Walzer, who, early in Just and Unjust Wars, affords it this backhanded compliment:

Some wars are not hell, and it will be best to begin with them. The first and most obvious example is the competitive struggle of aristocratic young men .... Examples can be found in Africa, ancient Greece, Japan, and feudal Europe. Here is a 'contention by arms' that has often captured the imagination, not only of children, but also of romantic adults. (1977: 25)

Walzer's remark about this ethos' appeal to 'children' and 'romantic adults' is perplexing. Are we to conclude that this code is itself romantic and childish? The quote demonstrates that Walzer was aware that this ethos was particularly favored by the very men who fought (the 'aristocratic men' he speaks of used to be called bellatori, which literally means 'those who fight' (Bell 2007: 31)). Surely it would be a mistake to call an ethos embraced by actual warriors a childish and romantic one. A resurrected warrior-aristocrat might in turn reply that JWT is an 'ivory tower' theory of war, invented and promulgated by academic monks, monkish academics, and legalistic jurists, each of whom made the mistake of foisting the ethical outlooks of the cathedral or courtroom onto war. Setting aside the snarkiness of this retort, it does contain a seed of truth: good applied ethics takes into account the thoughts and perspectives of practitioners. Good medical ethics takes into account what doctors say and do; good philosophy of law takes into account what lawyers and judges say and do; and so on. Yet ethicists generally have not taken seriously what warrior-aristocrats have said or have done. I think this is because, at the time of its development, theorists of just war simply assumed that moral understanding flowed down from philosophers, jurists, and theologians as water flows down a mountain. Few ethicists now think things work this way, and most of us agree that there is a great deal of wisdom operant in domains of life uninfluenced by systematic philosophical analysis, even if that wisdom hasn't yet been dressed up into a theory.

Ultimately, however, there is no way to prove to a skeptical audience that there is moral value to the warrior's code other than to articulate it 
and allow the reader to see for him- or herself how intuitive it is. That is the aim of this paper. Specifically, I attempt three things: first, to distill the honor ethos down to its unvarnished essence; second, to show how the warrior code is simply a martial expression of the honor ethos; and third, to argue that, since 'Honor War Theory' (HWT) describes a variety of present conflicts and predicts distinctive, persistent moral intuitions, HWT is neither out of touch with modern warfare nor obviously morally corrupt. My discussion proceeds in three steps. In §2, I articulate a general theory of the honor ethos that is cross-cultural and applies to both marital and non-martial spheres of life. In §3, I sketch some ad bellum and in bello principles of HWT, exposit upon some interesting contrasts between it and JWT, and explain why in some cases HWT seems better, both in its prescriptions and as an explanation for certain intuitions that JWT doesn't do an efficient job of accommodating. I conclude by conceding that HWT isn't superior to JWT, but that nonetheless any fully mature, 'unromantic,' and yet properly normative theory of moral war will incorporate some of its insights.

\section{The 'Competition Ethic' Account of Honor}

Although there is no shortage of expositions on bushido and discourses on chivalry, the warrior-aristocrat approach to war has never been shaped into a philosophically rigorous 'theory' of war ethics. Likewise, the more general honor ethos from which the code of the warrior extends hardly can be called an ethical 'theory.' Ethical theories are the product of some philosopher's attempt to systemize and guide moral thought by taking into account all sorts of moral intuitions, along with the reasons and values they reflect. An 'ethos,' at least as we mean it here, is the mindset constituted by just one cluster of these intuitions, reasons, and values. Ethicists must deal with each cluster in one way or another, either by accommodating or repudiating it in their theory 
construction. ${ }^{2}$ Heretofore we have mostly ignored those having to do with honor, especially as it is understood here. ${ }^{3}$

What are the principles of the honor ethos, once we abstract away from cultural particularities and divorce it from all other moral approaches? ${ }^{4}$ There are many, but we need only raise a handful here, beginning with this one:

HONORABLE GOODS: Goods gained in ways having nothing to do with competition—goods gained through mere work, luck, gifting, or fair dealing-lack moral value.

As opposed to the justice tradition, which sees 'goods' (typically: wealth, freedom, and welfare) as morally gained only if obtained in ways consonant with cooperative principles, the honor ethos sees goods as correctly gained-indeed, reason-providing-only if gotten agonistically. This is why warrior-aristocrats generally looked down on 'commercial men' and erected social conventions barring themselves from work and business. The ideal way to attain goods was to win them in battle, or in a prize competition or tournament, or by being gifted them by a grateful sovereign in recognition for military accomplishment. This competition central to honor is carried out in what we can call an 'honor arena,' a competitive forum that serves to rank people according to their exploits there. Two things are scrutinized in any honor arena: first, how good the competitors are at something (fighting, playing ball, musicianship) and second, how well they bear themselves in the heat of that competition

2 Cf. Moral Foundations Theory (Haidt \& Graham 2007; Haidt, Koller, \& Dias 1993; Heinrich, Heine, \& Norenzayan 2010). Whether honor is another moral foundation I must leave to another discussion. The point at present is that there is mounting empirical pressure on ethicists to take non-academically mainstream ethical modes seriously, even if doing so results in nothing more than rejecting them explicitly.

3 For contrasting views in philosophy, see Appiah 2010; Berger 1983; Cunningham 2013; Peter French 2002; Shannon French 2003; Gerrard 1994; Olsthoorn 2005; Sessions 2010.

4 Honor is the subject of a vast amount of anthropological, literary, and now psychological research. Readers familiar with that literature will observe that I am expositing on what might be called 'competitive honor' (Stewart 1994: 59-60). 
(Do they cheat? lose gracefully? show proper respect to their competitors? crumble under the pressure? etc.). Prestige is determined by one's performance in the honor arena. One risks losing all prestigerisks being positively dishonored - if one cheats in the honor arena, fails to show rank-appropriate respect to others, or fails to demand rankappropriate respect for oneself.

The importance of competition leads us to another principle of the honor code:

RANK DESERT: If a person's rank is deserved, it was won by successful challenge.

In a wide sense, any culture preoccupied with face or prestige is an 'honor culture.' Some may see 'honor' (in the sense of mere prestige) as a function of racial or spiritual purity: the whiter or more holy one is, the higher one's rank. Another might see prestige as properly gained or lost only authoritatively: God may anoint you, or a general demote you, depending upon how obedient you are. The 'honor ethos' proper distinguishes itself from these philosophies of deserved rank by basing desert of prestige on competition: you elevate your status only by challenging and defeating those above you, and lose prestige only by being defeated by challengers.

Of course, actual cultures are messy, and none has ever been completely guided by any one ethos. Even warrior-aristocratic cultures were often influenced by purity-type reasoning (they usually congratulated themselves on having the 'pure' blood of some favored race or caste) or authoritarian reasoning (average people are 'like children' whom the aristocrats must govern). But even so, such groups usually justified their social standing and inherited wealth by the agonistic exploits of some illustrious ancestor whose nobility was distinguished on the battlefield. Even aristocratic fops such as P. G. Wodehouse's Bertie Wooster, to comic effect, felt free to echo the hackneyed sentiment that, should push come to shove, 'blood will out'i.e., thrown into the trenches together, noble blood will distinguish itself 
in combat and the test of wills, proving that aristocrats really did deserve their social prerogatives.

These points take us to our third principle of honor:

FAIR PLAY: Competitions for prestige must be fair.

Competitive institutions, such as athletics, make extraordinary efforts on behalf of fairness. Honor cultures often impose the principles of fairness in sport onto war, where they adhere to the principle of a 'fair fight' in circumstances with the highest possible stakes. Take the scenario of catching your enemy's troops as they are crossing a river. According to the semi-historical song Battle of Maldon, the Saxon chieftain Byrhtnoth, upon finding a large force of Viking marauders across the Panta River in 991, allowed the Vikings to cross the river unmolested before launching his attack, since he thought attacking them while they were vulnerable would give him an unfair advantage. Byrhtnoth was defeated and killed. One website devoted to the poem calls this a 'victory of a peculiarly British character, ${ }^{5}$ but that evaluation is untrue. For instance, we learn from the ancient Chinese history Zuo Zhuan how Duke Hsiang of Sung intercepted attacking Ch'u troops as they were fording the Hung river in 683 B.C. The Duke, against advice from his subordinates, allowed the Ch'u to cross and form ranks. He was defeated, but unrepentant, declaring that

the gentleman does not inflict a second wound, or take the grey-haired prisoner. When the ancients fought, they did not attack an enemy when he was in a defile. Though I am but the unworthy remnant of a fallen dynasty, I would not sound my drums to attack an enemy who had not completed the formation of his ranks. (quoted in Fields 1991: 109)

Similar sentiments were sometimes endorsed in ancient India. Certain Vedas instruct warriors to fight fair in the most literal sense:

Elephants should oppose only elephants; and so the chariots, cavalry, and infantry only their opposite. [...] One should strike only after due notice ... [and never one] who is confiding or unprepared or panic-stricken ... or [one

5 N.a., Battle of Maldon.org.uk (2011). 
who is] without armor, or whose weapons are rendered useless ... or [one who is] fatigued and frightened, weeping and unwilling to fight; [or] one who is ill and cries for quarter, or one of tender years or advanced age. [In fact] a Ksatriya [a member of the warrior caste] should defend even his enemy if entreated with joined hands. (quoted in Singh 1965: 161-162)

Obviously, such rules are not designed to foster efficient fighting machines. They rather represent an ideal that saw battles as opportunities for antagonists to distinguish themselves in fair fights.

As opposed to those honor cultures that try to stabilize rank by means of authority, racial purity, etc., the honor ethos encourages an atmosphere in which rank is constantly being competed-for. This fact leads us to consider the constraints on challenges for rank. Here are a few:

RANK AMBITION: You must seek the highest rank you deserve, so you must challenge those slightly higher-ranked than you if you think you can defeat them.

RANK HUMILITY: But you must not challenge those much higherranked, and much higher-ranked parties cannot accept challenges from those much lower-ranked.

NO DUCKING: You must not decline legitimate challenges to your rank.

NO BULLYING: You must not challenge those of lower rank.

Ethicists tend to bristle at all this talk of 'rank,' 'status,' or 'prestige.' Knee-jerk hostility to honor's concern with rank and prestige can be ameliorated by distinguishing 'hierarchy' and 'rank' proper. Regimenting our natural language a bit, I suggest we reserve the word 'hierarchy' for rankings such that higher one's rank, the more power one has over the lower-ranked parties. On the other hand, let 'rank' concern prestige in the strict sense, according to which there is no suggestion that the higher-ranked party has any power over the lower-ranked party. Sports teams are placed in a 'ranking' as we usually put it, since the 
higher-ranked teams have no power over the lower-ranked teams. Military personnel are placed in a hierarchy, on the other hand, since to have a certain rank there is to be placed in a network of authority such that a higher-ranked party can tell a lower-ranked one what to do. This makes sense, since authority is sometimes needed to coordinate behavior and establish group cohesion in order to satisfy some further objective. Honor competitions have no 'higher' purpose, however: the aim of the game is merely to rank players or teams according to their competitive excellence. As we saw above, even wars were approached this way-as dangerous sport.

Although RANK AMBITION does require one to pursue the highest rank one can achieve, this should not be taken to mean that honor requires one strive for the highest rank one can be thought to deserve. Rather, it means that one should strive to the highest rank one actually deserves. ${ }^{6}$ It falls out of principles such as HONORABLE GOODS and FAIR PLAY that one isn't supposed to cheat, lie, wheedle, or flatter to improve one's status, even if such tactics would be successful-indeed, such actions are paradigmatically dishonorable. The honor ethos demands instead that we be quick to acknowledge the superiority of others, even if we covet their status. Those with a fine sense of honor feel deeply uncomfortable with praise suggesting they are higher-ranked than they feel themselves to be, and are quick to correct any misunderstandings on such matters, even when it would personally benefit them not to. Such acknowledgement has nothing to do with Christian humility: it is absolutely imperative for the honorable person to be sensitive to excellences displayed in the honor arena, to draw proper conclusions about the ranking these exploits reveal, and to discuss one's conclusions on these matters with others in the appropriate venues. Without these skills, how can one place oneself on the ranking? How can one know whom to challenge or emulate? How can one know

6 'It's important to understand that while honor is an entitlement to respect-and shame comes when you lose that title-a person of honor cares first of all not about being respected but about being worthy of respect' (Appiah 2010: 16). 
from whom to accept challenges? And how can one demand rankappropriate respect for oneself unless one is willing and able to extend rank-appropriate respect to others, based upon a shared opinion about who should be ranked where?

Honor must be periodically 'refreshed' by re-entry into the honor arena. One cannot rest on one's laurels for too long without justified skepticism as to whether one deserves one's reputation. A primary way for this refreshing process to occur is by accepting challenges issued by slightly lower-ranked parties (NO DUCKING). But according to RANK HUMILITY, one needn't accept challenges from a much lower-ranked party. This makes sense, since such parties haven't earned the right to challenge the much higher-ranked party. This principle is especially apparent to us when we consider insults, which are often sorts of challenges (the word 'challenge' is derived from the Latin calumnia-an insult or attempt to damage one's reputation (Jones 2000: 21)). We tend to take seriously, and feel obliged to respond personally, insults levied from peers or slightly lower-ranked parties. But almost instinctively we know that one mustn't reply to a much lower-ranked insulter, since that would do the insulter too much credit and only lend credence to her challenge (by the logic of honor, your reply would suggest you take her to be a worthy challenger). In healthy honor cultures, one's friends are supposed to reply on your behalf to the upstart's insult.

One need not be concerned about accepting challenges from higherranked parties, since there is a strong disincentive to challenge those lower-ranked than you (NO BULLYING). After all, to challenge a lowerranked party is detrimental to one's own status since the challenge can be fair-minded only if you see yourself as on par with the person you challenge. Nonetheless, sometimes higher-ranked parties challenge or invite lower-ranked parties to the honor arena. When initiated by a higher-ranked party who is alive to the honor-theoretic consequences of such an act, such challenges should be seen as praise, since it amounts to the higher party's wish that the lower-ranked party be publicly recognized as deserving higher status. Sometimes, however, a higher 
ranked party acts dishonorably, or has a bad sense of honor's demands, and uses (or tries to use) bullying tactics to reinforce her status. For instance, in the schoolyard ranking of toughness among boys, a strong boy 'bullies' when he aggresses upon a smaller boy. These bullies are usually condemned, and admonished by other children to 'pick on someone their own size.' Revealingly, only the schoolteachers or moralists tell students not to aggress on anyone, whatever his size. This fact suggest that the honor ethos must be appealed to in order to explain what is uniquely contemptible about the bully: bullies aren't despised because they are aggressive, but because they aggress against those weaker than themselves.

This handful of abstract principles by no means does justice to the richness and complexity of the honor ethos. Nonetheless, I think our feel for honor on the present account is adequate for our purposes. We now turn to analyzing the warrior code as a martial instance of the competition ethic.

\section{Principles of Honor War Theory}

In this section I canvass a few principles of 'honor ad bellum' and 'honor in bello.' With regard to honor's ad bellum constraints, I elaborate especially on HWT's acceptance of 'skirmish aggression' and say a little in favor of an ethic that allows states to aggress in this particular way. With regard to honor in bello, I take as read HWT's obvious commitment to good treatment of POWs and civilians, as well as Walzer's conclusion that HWT's consensual violence is not problematic and leads to less hellish wars (see Walzer 1977, pp. 25ff and 35ff, especially). So instead I focus on a couple of persistent and loosely-related intuitions surrounding riskless warfare that JWT has a difficult time accommodating. Some attempts to account for these intuitions have been based on the equality-especially the equal humanity-of belligerents. I argue that HWT does a more efficient job of explaining and justifying these intuitions, so it is likely that they are really manifestations of our (often undiagnosed) attraction to HWT. Thus, with 
regard both to ad bellum and in bello matters, HWT continues to inform our thoughts, feelings, and practices in war.

\subsection{Honor Ad Bellum}

The presentation of honor ad bellum that follows is guided chiefly by the competition ethic account of honor outlined above, but it is also deeply influenced by work in history and international relations that has helped illuminate the role of honor in war (Bell 2007; Joshi 2008; Kagan 1995 and 1997; Lebow 2010; O’Neill 1999; Robinson 2006). Before launching in, however, three cautions must be registered. First, it must be noted that comparing JWT and HWT on the question of when it is permissible to go to war is complicated by the fact that the warrior-aristocrat philosophy of martial violence was not oriented toward war so much as battle. For whether we are talking about Neolithic warriors or Old Regime European aristocrats, warriors of this turn of mind gained or lost prestige by way of frequent, comparatively smaller encounters on the periphery of their territories. ${ }^{7}$ I thus tend to speak of 'fighting' rather than 'warring.' Second, it should be remembered that we are looking at the honor-ethical approach to war, stripped of all other considerations coming from the directions of justice, care, beneficence, and so forth. Obviously, a satisfactory philosophy of war would take those values into account, too. (The controversial claim of this paper is that a satisfactory philosophy of war would pay honor similar respect.) Third, I speak of 'states' for simplicity, although HWT also pertains to non-state actors, such as a rebel force.

\footnotetext{
7 One must be wary of generalizations: the same tribe may wipe out an enemy with a sneak attack on Monday, and yet engage in tournament-style combat with another tribe on Tuesday. Reality is, again, messy, and we are talking about ideal types here. Nonetheless, it can reasonably be asserted by anthropologists that 'tribal warfare is relatively simple ... usually consist[ing] primarily of small-scale sporadic raiding occurring with limited physical contact' (Haas 1990: 177). Haas goes on to suggest that the 'objectives' of raid culture are material, but the recent revival of interest in honor suggests that, as Thucydides thought, the causes of war are 'honor, fear, and interest' (quoted in Kagan 1995: 8). With regard to the perpetual war of Old Regime aristocracies, see e.g., Bell 2007, Ch. 1.
} 
With those cautions registered, what are some principles of honor ad bellum? Here are two:

JUST CAUSE: A state may fight to protect or promote its prestige. A state may not fight to conquer or dominate, or to change the culture, religion, or minds of another state. Nor may a state fight to improve the world, be that 'improvement' political, moral, ethnic, or religious. Typically, a state may or even must fight if challenged, especially if gravely insulted. It must fight if it feels its prestige still warrants protecting its claim to some traditional prerogative or status symbol. However, if a state feels its status no longer warrants possession of that prerogative or symbol, it should concede it. A state may try forcibly to take some status symbol or prerogative from another state if doing so reflects a reasonable appraisal that it (the aggressor state) has risen in the international ranking. A state may sometimes intervene on behalf of another against a bullying dictator or a bullying third state.

LAST RESORT: Honorable states do not think of battle as allowable only as a last resort. (Only a contemptible polity that prized security, wealth, and life over honor would think this way.) A dispute of precedence is sufficient for justifying battle or even aggression. Nonetheless, a willing opponent is desirable, even if that opponent must be drawn out by insults and provocations.

The JUST CAUSE and LAST RESORT principles reflect a certain willingness to fight in circumstances roundly condemned by JWT. And yet HWT's logic is intuitive enough: whether in the schoolyard or in the academy, the desire to challenge one of the 'big boys' is usually thought of as honorable and spirited, even if foolhardy and imprudent. Thus, some unprovoked aggression is perfectly honorable.

Despite the superficial bellicosity of HWT, it acknowledges an important and genuine distinction between what we might call 'skirmish' aggression and 'conquering' aggression. Skirmish aggression involves challenging or attacking some peripheral military target or border area 
in order to raise one's status or to demand more respect from the global community. On the other hand, conquering aggression aims at replacing, for materially selfish reasons, the political authority of a state-or worse, at exiling, enslaving, or exterminating its people. Any variety of HWT will condemn conquering aggression. Nonetheless, the usual condemnation of conquering aggression by HWT does not leave a sophisticated version of it inflexible to what appear to be cases of legitimate regime-change. The motive must not be selfish or humanitarian, however. Recall that the competition ethic account explains why we find bullies contemptible and dishonorable: our devotion to fair fights spurs us to see the bully as dishonorable, and not merely unjust, because he attacks those weaker/lower-ranked than himself. Applied to international relations, when some tyrant is oppressing the people of his country, it will probably not be seen as dishonorable for even a much stronger country to depose the tyrant. In effect, the intervening state plays the role of the noble student intervening against the bully on a weakling's behalf. Whether such actions are prudent, or work out to the benefit of the global community, etc., are different and important questions, but it is usually honorable for stronger/higher-ranked parties to check bullies.

When it comes to ad bellum concerns, JWT and HWT part ways most dramatically when it comes to skirmish aggression. Take the case of Sino-American relations over the past ten years. Militarily, China is regarded as the United States' inevitable rival for superpower status. ${ }^{8}$ China for its part welcomes this role, and it apparently endorses a certain amount of skirmish aggression. So far, that aggression has mostly been located in cyberspace, or aimed at U.S. reconnaissance ships and planes sailing or flying just outside of Chinese territory (Rogin 2010; Sanger 2001; Shanker and Mazztti 2009). The U.S. usually protests such

\footnotetext{
8 According to one report, the U.S. is preparing for this eventuality: the lion's share of U.S. strategic resources are devoted to the Pacific Command, or PACOM, despite the fact that the conflicts in Iraq and Afghanistan fall inside the province of Central Command, or CENTCOM (Kaplan 2005).
} 
'aggression' because it is illegal. Of course, the U.S. is correct about that point of legality, and from the perspective of justice the Chinese are doing something wrong. But on HWT these cases of Chinese harassment are perfectly permissible. After all, the Chinese are flexing their muscles, raising themselves in a ranking of military power they-and the U.S.find honor-conferring (RANK AMBITION). They are aggressing upon a more powerful nation (NO BULLYING), choosing targets for their aggression in the periphery of their influence, and are not in any way signaling an intent to conquer the U.S.

The Falklands War was an obvious case of skirmish aggression. In April of 1982, Argentina attacked the Falklands and forced the surrender of the few dozen British marines stationed there. Since the Falklands have negligible strategic value, the Argentines miscalculated that the British would let the matter be, especially given Britan's economic and military malaise at the time. But as it happened, the British undertook a surprisingly expensive and deadly campaign to reclaim the Falklands. Britain succeeded in wresting back the islands, British patriotism revived, and the incident led Britain to recommit to its long-neglected armed forces. The Argentinean military-led government was shamed and replaced with a democratically-elected one led by an outspoken critic of the war.

According to HWT, Argentina's wholly unprovoked attack on the British outpost was honorable, at least insofar as Argentina attacked a more powerful country (RANK AMBITION) on the latter's periphery, with no intent to conquer. One might argue that the action was dishonorable insofar the action bordered on violating RANK HUMIILTY, since one might reasonably think that Argentina bit off far more than it could chew in challenging Britain. Yet it wasn't unreasonable to suppose that the British would blink and concede to a negotiated peace (and indeed Britain's resolve surprised many observers), so we should probably conclude that Argentina satisfied the constraints of honor ad bellum. Because it abandoned in defeat its attempt on the Falklands, Argentina ceded prestige to Britain: for 
although Argentina and Britain were not equal adversaries all-told, Britain's response was more measured, its battlefield more distant, and its stakes much lower, and these considerations have an equalizing effect.

It would appear that the Clausewitzian logic-that war is in principle boundless because it invites the application of progressively more force until war becomes total (Clausewitz 1832/1976) - is obviated in part by a tacit understanding between states of the nature of skirmish aggression. Skirmish aggression amounts to testing, probing, or perhaps prodding or elbowing, in the effort to improve status. If you prod softly (as the Chinese continue to do against the U.S.), you are pushed back softly-if pushed back at all. If you skirmish-aggress more forcefully, then you are inviting a more forceful response (as in the case of the Falklands). But even if you aggress very forcefully, if that aggression is taken as skirmish aggression, you have the right to expect only a response limited to the area of the skirmish. For instance, even if Argentina committed its full might to fighting for the Falklands, Britain would have had only the options of either ceding the territory or fighting for it in the Falklands. Attacking Argentina proper would be dishonorable, since Argentina, even in this case, could not be seen as attempting to conquer the British people.

Skirmish aggression requires some territory, real or virtual, that is either contested (today: the Senkaku Islands, Kashmir) or a no-man's land (international waters, the arctic). Thus, the hardening of borders, and our justice-based habit of seeing any aggression as criminal, makes skirmish aggression difficult to carry out or even to understand. Now if states were satisfied with their borders or spheres of influence, or if all parties were prepared to abandon the notion that national prestige is partially fixed by such things, then these two justice-based tendencies would be unobjectionable. But since some powers are not happy with their borders, and since some states wish to play the military honorgame in what they take to be no-man's lands or contested zones, then other nations seem forced deal with skirmish aggression, whether they 
wish to or not. It would behoove everyone involved to deal with such aggression by the rules of honor, and not justice.

To see why, suppose country A attacks some outposts of country B. This might involve lobbing, in a haphazard manner, a few missiles at a military base just inside B's borders. Because of the (intentionally) sloppy and inefficient nature of the attack, A signals that it is not intent on taking that territory. From a simple justice perspective, this is an unjustified harm to $\mathrm{B}$, and justice demands that $\mathrm{A}$ immediately cease its attacks and be punished in some way-perhaps through a combination of reparations and some reprobative language from the U.N. But what if A refuses to pay any reparations or to stop its harassing attacks on B? If all attacks are understood in terms of justice, then B and all advocates of international justice are required to use force to stop A or even to punish A. Executing this justice might be extremely costly in terms of lives and money, especially if A is a militarily or economically powerful country. But failing to execute justice (or worse yet, failing even to try to execute justice) makes a mockery of 'international law' and morally indicts the bystander nations. Justice does not allow us merely to let the issue drop. HWT, however, provides us with some much-needed flexibility here. If A's attacks are reasonably seen as a case of skirmish aggression, B can (proportionally) respond, and continue to ramp up its response to whatever extent it feels warranted given its potential loss of prestige. But crucially, B and its allies are not required to press the issue. They may simply give in (say, by removing the bases, or by granting some concession A was demanding). In that case, B and its allies have ceded some prestige to A. Because there is no requirement to punish or even put an end to A's skirmish aggression, $\mathrm{B}$, it allies, and the global community are not obliged to elevate their response, potentially to the limit of their abilities.

\subsection{Honor In Bello}

The competition ethic account of honor justifies a variety of in bello principles that can readily be appreciated as constitutive of the warrior's code. Here are six: 
WAR CONVENTIONS: Honor requires that prestige be allocated by the outcome of fair competitions. Many types of conventions would be fair. It is incumbent upon belligerents to agree, at least tacitly, to a fair convention in order to minimize unfair advantage, needless offense, and excessive suffering. Once agreed upon, those conventions must be scrupulously obeyed, but may be modified by common consent.

COMBATANTS: HWT licenses the belligerence of warriors against warriors when that violence is consensual and fair. Thus, any convention agreed to by the belligerents should try to include prohibitions against attacking unprepared, dispirited, and retreating enemies. Admittedly, belligerent parties might be so intent on discouraging unpreparedness, loss of spirit, and cowardice that they actually agree to conventions allowing warriors to attack opponents in those circumstances. Nonetheless, they should do so with the understanding that such attacks undermine the spirit of the warrior ethos.

NON-COMBATANTS: In order to elevate or protect status, warriors seek fair fights. Civilians and prisoners of war are thus obviously not proper targets, because they cannot fight on fair terms. Battlefields should be selected that minimize the harm to noncombatants and signal to the enemy that any aggression involved is skirmish aggression.

POWs: Warriors use their violence only in fair combat, never on those who are defenseless or cease to fight. Prisoners should be afforded respect and significant freedom. Prisoners with good reputations may be paroled if they promise not to resume the fight. Warriors are not to execute justice by punishing prisoners who have committed war crimes-punishment concerns justice and justice is to be handled by some international body or, failing that, the justice system of the state. 
POLICE ACTIONS: Warriors are never to be used as police, since police are not honorable: police use force against criminals as opposed to honorable foes, and use overwhelming force in the service of justice (or worse, authority).

NON-HONORABLE WARS: Warriors cease to be warriors when they are faced with dishonorable or non-honorable foes such as pirates, true terrorists, religious fanatics, assassins, mobs, conscripts forced into a war of conquest, protestors using passive resistance, etc. Just as JWT is silent on the moral rules of the consensual combat of warriors, HWT is silent on what the moral constraints are in those circumstances. Generally, HWT will countenance the warrior's abandoning the rules of honor if he is aggressed upon by a dishonorable foe. But warriors will make reasonable efforts to foster a shared sense and commitment to honor between themselves and the enemy. In any case, warriors are not, qua warriors, obliged to fight for their nation in non-honorable disputes, although perhaps as citizens they should willingly take up arms as soldiers. Protesters using passive resistance measures are particularly perplexing to the warrior; whatever the correct response is to such groups, it does not involve warriors and no warrior seeing himself as such can exert violence on peaceful protestors or passive resisters.

Obviously, HWT's characteristic in bello principles are more easily called 'romantic' than their ad bellum counterparts. But this is precisely because they are particularly attractive. They also speak to intuitions non-honorbased theories of war have a difficult time accommodating.

For instance, consider our intuitions about drone strikes on vastly inferior military targets, or the sniping of defenseless or unprepared soldiers. Whatever our all-things-considered views about such matters, both seem problematic. One way philosophers have tried to accommodate our intuitions against such tactics has been by appeal to a general commitment to the equality of soldiers, which is in turn 
understood in terms of their equal humanity. For example, Walzer connects equality to humanity in his memorable discussion of 'naked soldiers': cases in the historical account of soldiers (often snipers) unwilling to kill bathing, naked, oblivious, shell-shocked, frolicking, or otherwise ridiculous enemy combatants. After recounting some cases, Walzer muses,

It is not against the rules of war as we currently understand them to kill soldiers who look funny, who are taking a bath, holding up their pants, reveling in the sun, or smoking a cigarette. The refusal of these [snipers to kill such people], nevertheless, seems to go to the heart of the war convention. For what does it mean to say that someone has a right to life? To say that it is to recognize a fellow creature, who is not threatening me, whose activities have the savor of peace and camaraderie, whose person is as valuable as my own. An enemy has to be described differently, and though the stereotypes through which he is seen are often grotesque, they have a certain truth. He alienates himself from me when he tries to kill me, and from our common humanity. But the alienation is temporary, the humanity is immanent. It is restored, as it were, by the prosaic acts that break down the stereotypes .... Because he is funny, naked, and so on, my enemy is changed ... into a man. (Walzer 1977: 142)

So although Walzer thinks JWT allows unfair killing, he thinks our intuitions against it stem from our recognition of the enemy's humanity.

Or take Shannon French's remarks about drone strikes in her Code of the Warrior (2003). French advances a very different view of the warrior than that presented here: hers is what we might call a 'therapeutic' theory of the warrior code. French sees the warrior code as that which distinguishes the warrior from murderers in his own eyes, (1-5). French discusses fascinating research suggesting that a key cause of posttraumatic stress is the soldier's appraisal of his enemies as subhuman and dishonorable, and thus his own fight with them as lacking honor. Since French sees no other essence in warrior codes than their function of distinguishing warriors from murderous killers (231ff), it follows that a warrior code will tend to block the common tendency to see the enemy as less than human (as evidenced by labels such as 'gooks' or 'ragheads'). By extension, the warrior code will also see something wrong with 
depersonalizing the enemy or making them 'virtual'-and this is what is problematic about the super-efficient, remote-control warfare now available with technologies such as the Predator drone (11ff).

Now I think that HWT does a better job of explaining our intuitions here. Against Walzer, it seems that the 'shared humanity' he elaborates on in the above passage is irrelevant to our hesitations about sniping naked soldiers, and it seems psychologically implausible that we 'have to' dehumanize someone bent on killing us. With regard to the first claim, the simpler explanation for the wrongness snipers sometimes perceive in killing bathing, frolicking, or shell-shocked enemies is that (whether or not the snipers would use the term) it would be dishonorable. It would be dishonorable because honor demands some sort of fair combat, which means a rough equality in lethalness. Even some of the snipers Walzer quotes suggest as much. ${ }^{9}$

With regard to Walzer's moral-psychological claim that we must dehumanize the enemy, it is worth pointing out that this psychological maxim certainly does not hold in honor cultures that train up warriors. The warrior is emphatically not inclined to dehumanize his enemy merely because he is trying to kill him. In fact, the honor tradition favored up-close-and personal combat precisely because it was thought that only then can your opponent's true qualities be assessed (Hatto 1940). The Hausa of Africa, who had a warrior-aristocratic tradition that resembled our own, had a saying to express their disdain for ballistic weapons such as bows and arrows (the sniper rifles of their day): 'Only when it is breast to breast does one know a great man' (Illife 2005: 15). It was not unusual for warrior-aristocrats to dine with their enemies after battle or to publicly sing their praises. The apotheosis of the warrior,

\footnotetext{
${ }^{9}$ Walzer quotes one sniper:
}

I reasoned like this: To lead a hundred, even a thousand, men against another hundred, or thousand, was one thing; but to detach one man from the rest and say to him, as it were: 'Don't move, I'm going to shoot you. I'm going to kill you'-that was different .... To fight is one thing, but to kill a man is another. And to kill him like that is to murder him. (quoted in Walzer 1977: 142) 
Richard I, was so singularly motivated by the honor ethos that, in the midst of a religious crusade, he offered Saladin's brother Salafin-whose son Richard had knighted-his sister, Joanna, as a wife, the idea being that Salafin and Joanna could rule Jerusalem. (Joanna surprised Richard by her lack of enthusiasm at the prospect of marrying such a noble and chivalrous Muslim prince. As an afterthought Richard suggested that perhaps Salafin's conversion could be part of the deal (Regan 1999, p. 190). ${ }^{10}$ Whether fully successful or not, the honor ethos encourages us to personalize the enemy and see ourselves like them.

French herself might have pointed this out. After all, her insight is in part that the warrior code has humanized enemies from time immemorial. Nonetheless, French's therapeutic account of honor provides us with a contingent and instrumental rationale for humanizing the enemy that doesn't ground as strong a case for honor in bello as the one provided here. For surely we can imagine a pill that would avert the psychological harm a Marine would suffer after gunning down Vietnamese villagers, or a serum that would obviate a drone pilot's mental anguish upon blowing up depersonalized targets on a computer screen. In such situations, what would the value of the warrior code be on French's view? What we need is an account that conceptually, not contingently, explains our sense that the warrior must see his enemy as his moral equal, eschew atrocity, and avoid unfair fights. The competition ethic account outlined above provides such a story. As players in the honor-game in which battle is the honor arena, there is no incentive for the warrior to fight those of lesser military status, only those equallyranked or higher. This accounts for the repellent nature of drone strikes and the mistreatment of POWs and civilians. Moreover, as long as our equally-matched opponents play by the rules, they are the same as we

10 That is not to say any honor war theorist would hold Richard I up as a model: Richard, like many people of his day, extended the honor ethos only to aristocrats, and felt little compunction about committing atrocities against common people. Articulating HWT is important not only for audiences who disparage it, but also for devotees who have a primitive conception of honor. 
are, different only insofar as they wear a different uniform. This accounts for the sense that one's enemy is a respectable moral equal.

\section{Conclusion: HWT's Relevance Today}

HWT is plainly false if it is taken as the complete truth on war ethics. Storming bin Laden's compound was a good thing. Various drone strikes are morally permissible and even obligatory. However, HWT is an accurate representation of one facet of moral war. Or, perhaps we should say it is an accurate representation of the rules for a certain sort of war: a set of battles for prestige.

Consider ad bellum constraints again. China is fighting for its 'face' against other world powers by aggression it takes to be on the periphery between it and them (Taiwan, Tibet, the Senkaku Islands, cyberspace, international waters). North Korea was fighting for prestige when it bombarded the island of Yeonpyeong in 2010. Russia is fighting to regain its lost prestige, as evidenced by its recent aggression in Georgia, which is on the geo-political periphery between Russia and the West. Prestige plays a role in the dispute over Kashmir. Prestige wars between various powers in the arctic will inevitably shadow their strategic energy interests. There is no shortage of historical precedent for honormotivated war (see Kagan 1995; Lebow 2010; O'Neill 1999; and Robinson 2006 for in-depth discussions), and it is imperative that we acknowledge these wars for what they are and evaluate them by the proper standards. Some reasons for doing so were given above. But we might add here that even critics of HWT might applaud the effects of a revived HWT tradition. HWT would probably be more attractive to nonliberal, honor-based cultures than JWT has proven to be. So perhaps HWT's proscriptions might carry more clout in the moral economies of those cultures if it were discussed in an unapologetic manner by theorists and opinion-makers. For instance, a consensus reached between Chinese and Westerners on what HWT demands might result in a redirection of Chinese skirmish aggression away from Tibet and toward less harmful battlefields, real and virtual. Or consider how a strengthened 
appreciation of HWT would also help cool the demagoguery and moral outrage of jingoist American pundits whenever China skirmish-aggresses on the U.S. After all, it is much easier to be outraged by the normal elbowing of a rising power when all aggression must be called 'criminal.'

A morally robust and yet non-romantic war ethic might well inherit some commitments to the warrior code with respect to in bello concerns as well. There have been some important efforts to revive the warrior code in order to prevent atrocity and to reestablish the U.S.'s self-image as a moral military power (along with French 2003, see Ignatieff 1997 and Osiel 1999). Although these accounts do not attempt to provide a systematic presentation of the warrior code and sometimes color their presentation of it with commitments foreign to the honor ethos as understood here, all sides agree that it is a good thing for soldiers, who are often free to kill or humiliate POWs and suspected but undeclared enemies with impunity, to have a self-oriented motive for restraint. If seeing themselves as 'warriors' is what it takes for soldiers to feel that self-oriented restraint, then so be it.

Of course, it should be obvious from the above that I think soldiers are not warriors. The paradigmatic warrior at best tolerates having a commander, often refuses to fight if not afforded proper respect by his comrades or superiors, and may even switch sides if he feels insulted or unappreciated (think of Achilles). As Montesquieu put it one place,

Honor prescribes nothing more to the nobility than serving the prince in war. In effect, this is the most distinguished profession because hazards, successes, and even misfortunes lead to greatness. But, in imposing this law, honor wants to be the arbiter; and if it finds itself offended, it requires or permits one to retire to one's home. (quoted in Krause 2002: 55)

So it is no insult to say that soldiers are not warriors. We need soldiers to fight wars that don't concern prestige, such as those against conquering aggressors. But given that we use the same men and women to fight all our wars, it is imperative that we awaken their sense of honor and equip them with the theoretical tools for identifying when the context has shifted from one domain or another. Do militants from group A attack 
civilians and behead captured soldiers? Then treat militants from A a certain way-perhaps a way dictated by JWT. Do militants from group B make an effort to attack your bases and military personnel, and try to exchange captured soldiers? If so, then that matters: there is a real possibility that such militants might prefer honorable warfare. Given the vast superiority of Western military training, technology, and infrastructure, along with our efficiency-minded endorsement of overwhelming force doctrine, a stand-up fight against any Western force is rarely a possibility. So even if B uses underhanded methods such as IEDs or suicide bombers dressed as support staff, their focus on military targets and (relatively) good treatment of POWs would hint at a desire to fight honorably. So it won't do to lump A and B together-both A and B may indeed be enemies, insurgents, militants or even terrorists, and yet they are nonetheless importantly different. Group B's emissaries deserve more respect, as do their captured members. Moreover, the reason for this increased respect should be communicated to them, since it may encourage B's members to maintain and deepen their commitment to fighting in honorable ways beneficial to the local populace and future diplomatic relations after Western forces withdraw.

Moreover, a general sense among soldiers that you morally can try to kill someone without their being evil or criminal would go a long way toward ameliorating the animosity, recrimination, and demonization so common in wars lacking honor. Those on both sides of the political spectrum have encouraged the sense that our enemies must be 'evil doers' or 'bad guys' or 'criminals' who break 'international law,' since both sides of the political spectrum feel pressured to justify war this way. Soldiers are influenced by this rhetoric, and it translates to their behavior on the battlefield and in the prison camp, where fine-grained distinctions between evil and/or criminal governments on the one hand, and morally innocent fighters on the other, are usually overlooked. And in fact those distinctions are blurry: it seems to me that many of the Western soldier's enemies today actually do have evil motives. Nonetheless, it is not incomprehensible that at least some enemy 
combatants are not evil, and it is certainly imaginable that some future enemy combatants will not be-that would merely be returning to the historical norm, after all. In light of such eventualities, it would seem advisable that in the meantime we keep the embers of honorable warfare burning in the hearts of our soldiers.

For it wouldn't overstate things to note that that the psychology of contemporary soldiers is itself a warzone. Their official military codes are dominated by the justice ethos. But increasingly public justifications for war and our conduct within it seem to be utilitarian in nature. This justice-utility tension is complicated by the recent addition of care-ethical motives: the remarkable success of Western militaries in humanitarian missions (such as their responses to the 2004 Pacific tsunami and the Haiti earthquake of 2010) have been capitalized upon in recruiting commercials aimed at activating care-based intuitions. Added to this mix are the conservative Christian commitments that many U.S. soldiers adhere to, which perpetuate the idea that the wars in Islamic countries are against an ancient and diabolical foe (cf. General Boykin's public comments to this effect in 2003 (Jehl 2005)). Proponents of all four outlooks wrestle for the soldier's conscience. But none of these views provides a framework that does as well as the honor ethos at fostering respect for the enemy as an enemy. The justice ethos encourages us to see others as either cooperative or criminal. Utilitarianism has no structural commitment to respecting enemies, since utilitarianism (as a consequentialist theory) is necessarily compatible with any attitude toward the enemy that would maximize utility. Care ethics is especially weak for ordering our thoughts when it comes to enemies, or even mere opponents. Christian ethics likewise discourages the having of any enemies whatsoever; but in the hands of extremists, the cross has often enough been hoisted as a banner in holy wars.

Of course, a philosopher can always nuance an ethos in the attempt to accommodate intuitions coming from directions inimical to it. Kahn's principle of mutual self-defense is an instance of this on behalf of the justice ethos, and it may be successful, as far as it goes. But at some point 
the epicycles we add to an ethos in order to make it accommodate all our intuitions only denature it and undermine its original appeal. I recommend a more theoretically honest approach, one recognizing that honor ethics is the natural ethic for respectful, fair minded, and deadly intercourse between people. Discussing this ethos in its unvarnished state would complicate the moral sensibilities of military personnel even further. Its principles would frequently be overruled because of commitments coming from other directions. Often they should be. But the honor ethos would also motivate belligerents, as it did Richard and Saladin, to develop lines of informal communication so that mutual respect can have a chance to take root. Mutual respect at the level of fighters (who even today often become our political leaders) is essential to the long-term good of both the Western occupying force and its nonWestern opponent. It is even more crucial when enemies are neighbors.

University of Minnesota, Morris

ddemetri@morris.umn.edu

\section{References}

Appiah, Kwame Anthony. 2010. The Honor Code: How Moral Revolutions Happen (New York: Norton).

Bell, David. 2007. The First Total War: Napoleon's Europe and the Birth of Warfare As We Know It (Boston: Houghton Mifflin).

Berger, Peter. 1983. 'On the Obsolescence of the Concept of Honor' in Revisions: Changing Perspective in Moral Philosophy (Notre Dame: U Notre Dame P).

Bonadonna, Reed. 2010. 'Honor and Character,' Journal of Character and Leadership Integration 1.2: 25-35.

Clausewitz, Carl von. 1832/1976. On War, M. Howard and P. Paret, eds. (Princeton: Princeton UP).

Cunningham, Anthony. 2013. Modern Honor (New York: Routledge).

Fields, Rick. 1991. The Code of the Warrior: In History, Myth, and Everyday Life (New York: Harper Perennial). 
French, Peter. 2002. 'Honor, Shame, and Identity,' Public Affairs Quarterly 16.1: $1-15$.

French, Shannon. 2003. Code of the Warrior (Lanham: Rowman and Littlefield).

Gerrard, Steve. 1994. 'Morality and Codes of Honour,' Philosophy 69.267: 69-84.

Haas, Jonathan. 1990. The Anthropology of War (New York: Cambridge UP).

Haidt, Jonathan and Jesse Graham. 2007. 'When Morality Opposes Justice: Conservatives Have Moral Intuitions that Liberals May Not Recognize' Social Justice Research 20.1: 98-116.

Haidt, Jonathan, Silvia Koller, and Maria Dias. 1993. 'Affect, Culture, and Morality, or Is It Wrong to Eat Your Dog?' Journal of Personality and Social Psychology 65.4: 613-628.

Hatto, A. J. 1940. 'Archery and Chivalry: a Noble Prejudice,' Modern Language Review 35: 40-54.

Henrich, Joseph, Steven Heine, and Ara Norenzayan. 2010. 'The Weirdest People in the World?,' Behavioral and Brain Sciences, 1-75.

Ignatieff, Michael. 1997. The Warrior's Honor: Ethnic War and the Modern Conscience (New York: Holt).

Iliffe, John. 2005. Honor in African History (Cambridge: Cambridge UP).

Jehl, Douglas. March 4, 2005. 'Report Urged Action Against General for Speeches,' New York Times.

Jones, George Fenwick. 2000. Honor Bright: Honor in Western Literature (Savannah, GA: Frederic C. Bell).

Joshi, Shashank. 2008. 'Honor in International Relations,' Working Paper Series, Weatherhead Center for International Affairs.

Kagan, Donald. 1995. On the Origins of War and the Preservation of Peace (New York: Doubleday).

April 1997. 'Our Interest and Our Honor.' Commentary.

Kahn, Paul. 1999. 'War and Sacrifice in Kosovo', Report from the Institute for Philosophy and Public Policy 19.2/3.

2003. 'The Paradox of Riskless Warfare' Philosophy and Public Policy Quarterly 22.3.

Kaplan, Robert. June 2005. 'How We Would Fight China,' The Atlantic Monthly.

Krause, Sharon. 2002. Liberalism With Honor (Cambridge: Harvard UP). 
Lebow, Richard Ned. 2010. Why Nations Fight: Past and Future Motives for War (New York: Cambridge University Press).

N.a. 2001. Battle of Maldon.org.uk

Olsthoorn, Peter. 2005. 'Honor as a Motive for Making Sacrifices,' Journal of Military Ethics 4.3: 183-197.

O’Neill, Barry. 1999. Honor, Symbols, and War (Ann Arbor: University of Michigan Press).

Osiel, Mark. 1999. Obeying Orders (New Brunswick: Transaction).

Regan, Geoffrey. 1999. Lionhearts: Saladin, Richard I, and the Era of the Third Crusade (New York: Walker and Co).

Robinson, Paul. 2006. Military Honour and the Conduct of War (New York: Routledge). 2007. 'Magnanimity and Integrity as Military Virtues,' Journal of Military Ethics 6.4: 259-269.

Rogin, Josh. Feb. 22, 2010. 'The Top 10 Chinese Cyber Attacks (That We Know Of),' Foreign Policy.

Sanger, David. April 3, 2001. 'Collision With China: The Overview,' New York Times.

Sessions, Lad. 2010. Honor for Us (New York: Continuum).

Shanker, Thom and Mark Mazzetti. March 10, 2009. 'China and U. S. Clash Over Naval Fracas,' New York Times.

Singh, Sarva Daman. 1965. Ancient Indian Warfare: With Special Reference to the Vedic Period (Delhi: Motilal Bararsidass Publishers).

Stewart, James Henderson. 1994. Honor. (Chicago: U of Chicago P).

Walzer, Michael. 1977. Just and Unjust Wars (New York: Basic Books). 